\title{
Functional structural change of lean and pulled industrial production system: the flexibility case
}

\author{
Mudança estratégica funcional de sistema produtivo industrial \\ enxuto e puxado: o caso de flexibilidade \\ Manoel Gonçales Filho ${ }^{1}$ (D), Pedro Domingos Antoniolli², Silvio Roberto Ignácio Pires ${ }^{3}$ \\ ${ }^{1}$ Universidade Metodista de Piracicaba - UNIMEP, Programa de Pós-graduação em Administração - PPGA, \\ Piracicaba, SP, Brasil. E-mail: manoel.filho1@a.unimep.br \\ ${ }^{2}$ Faculdade de Tecnologia do Estado de São Paulo - FATEC, Campinas, SP, Brasil. E-mail: prdanton@unimep.br \\ ${ }^{3}$ Fundação Getúlio Vargas - FGV, São Carlos, SP, Brasil. E-mail: sripires@fgvmail.com
}

How to cite: Gonçales Filho, M., Antoniolli, P. D., \& Pires, S. R. I. (2020). Functional structural change of lean and pulled industrial production system: the flexibility case. Gestão \& Produção, 27(3), e4385. https://doi.org/10.1590/0104-530X4385-20

\begin{abstract}
The present work aims to present an application of Lean Production and its tools in the production process of an industry manufacturer of furniture for industrial refrigeration. A strategic change was made and results were evaluated, considering the comparison between the current and future situation in the design of production volume, product characteristics, manufacturing time, and process analysis in relation to wastes, defects and storage of unnecessary materials, which can increase the cost of the final product. Likewise, the reduction or elimination of resources is also a trend from a sustainability perspective, as these inefficiencies can lead to increased consumption generated in production and impact the environment. Considering the importance of the Production Strategy aligned to the operations as a priority for the achievement of positive results, a theoretical, exploratory, bibliographical and descriptive reflection was carried out. The research conducted is of an applied nature and the methods of inductive and comparative approach have been adopted. The applicability of the Lean Production concepts and tools was analyzed and, through a case study, the productive process of the industry was investigated. The contribution is to certify that with the adoption of lean tools and thinking, it is possible to eliminate wastes, promoting improvements in the manufacturing process, and measuring financial gains. As a practical result, this strategic business reorganization reduced costs and improved the process, which has given rise to the level of competitiveness in a globalized economy.
\end{abstract}

Keywords: Strategy; Lean production; Furniture for refrigeration.

Resumo: O presente trabalho tem como objetivo apresentar uma aplicação da Produção Enxuta e de suas ferramentas no processo produtivo de uma indústria fabricante de móveis para refrigeração industrial. Foi realizada uma mudança estratégica e apuraram-se os resultados, considerando a comparação entre a situação atual e futura na concepção do volume de produção, características do produto, tempo de fabricação, e pela análise do processo em relação aos desperdícios, defeitos e armazenamento de materiais desnecessários, que podem aumentar o custo do produto final. Da mesma forma, a redução ou eliminação de recursos também é tendência em uma perspectiva de sustentabilidade, pois essas ineficiências podem levar ao aumento do consumo gerado na produção e impactar o meio ambiente. Considerando-se a importância da Estratégia de Produção alinhada às

Received Oct. 16, 2017 - Accepted Feb. 19, 2018

Financial support: Coordenação de Aperfeiçoamento de Pessoal de Nível Superior - Brasil (CAPES) - Código de Financiamento 001.

This is an Open Access article distributed under the terms of the Creative Commons Attribution License, which permits unrestricted use, distribution, and reproduction in any medium, provided the original work is properly cited. 
operações como prioridade para a conquista de resultados positivos, foi realizada uma reflexão teórica, exploratória, bibliográfica e também descritiva. A pesquisa conduzida é de natureza aplicada e adotou-se os métodos de abordagem indutivo e comparativo. Analisou-se a aplicabilidade dos conceitos e das ferramentas da Produção Enxuta e, por meio de estudo de caso, investigou-se o processo produtivo da indústria. A contribuição está na certificação de que com a adoção das ferramentas e pensamento enxutos, é possível se eliminar os desperdícios, promovendo melhorias no processo de fabricação, e mensurar ganhos financeiros. Como resultados práticos, essa reorganização estratégica empresarial reduziu custos e aperfeiçoou o processo, o que proporcionou o aumento do nível de competitividade em uma economia globalizada.

Palavras-chave: Estratégia de produção; Produção enxuta; Móveis para refrigeração.

\section{Introduction}

Refrigerators industrial production increased between 2000 and 2014 due to the stabilization of the Brazilian economy, as well as new markets opening. The economic stabilization provided investments attraction, greater competitiveness and, consequently, an effective increase in the demand for quality in goods manufactured and equipments. This same trend of growth can be observed in every household appliances lines, classified as "white line", which includes refrigerators, stoves, ovens, among others. The upward trend in exports occurred until the year 2009, and in the following years there was a reduction due to the global crisis and global competition increase.

The domestic market for refrigerators occupies the third place among electrical and electronic products and appliances, most present in Brazilian households. According to data from the National Association of Manufacturers of Electronic and Electrical Products (ELETROS, 2014), in 2012 there were more than 60 million refrigerators in Brazilian households.

Given this scenario, there are studies and initiatives to adapt strategies and technologies applied not only to equipments manufacturing, but also into the effective productive process technological evolution as a whole, which aim at higher productivity. On the other hand, in the area of refrigerators, Ruan \& Xu (2011) indicated an increase of more than six million of discarded refrigerators, mainly those of domestic use, which contains a large quantity of recyclable materials such as steel, copper, aluminum, plastics, glass and others.

According to Kondo et al. (2001), the reuse of refrigerator components by its disassembly can reach $30 \%$, while the combination of disassembly with the separation and grinding of the component other parts can lead to a reuse rate of close to $80 \%$.

Thus, the correct treatment of disposal and reuse becomes important, both economically and environmentally, with the life cycle of such equipments becoming shorter and shorter.

On the other hand, the issue of energy efficiency, linked to the production process and the use of residential and industrial refrigerators, should be taken into account. Thus, components quality, and the assembly adequacy in the production process generate relevant social impact, considering that these equipments are among main responsibles for the residential electricity consumption in a residence, together with the electric shower.

The application of Lean Production (LP) brings several outcomes for industry in terms of productivity, and available resources use optimization. Among these factors, it is worth highlighting the LP relationship with the environment, and 
products / processes development, which aims to allow a lower environmental impact.

Lean processes are importante to add value for organizations. In this sense, value added is obtained, according to Rother \& Shook (2003), from flows that include all the essential activities through which the product passes, and during these activities execution, the product receives value. From this perspective, Caffyn (1999) considers that added value comes from continuous improvements, also being an innovation source.

In this sense, Womack \& Jones (2004) explain that the purpose of the LP is the elimination of any waste, since they do not add value to the product, they also destroy the value obtained by the product or service in the previous activities. In this way, LP delivers superior performance to customers, employees, and other stakeholders (Bhasin, 2012).

According to Porter \& Linde (1995), production processes inefficiencies, based on consumed resources, cause waste, defects and storage of unnecessary materials, which also increase the final product cost. Thus, from a lean point of view, such resource inefficiencies must be minimized because they do not contribute to the product or service added value. Authors report that the reduction or elimination of non-added resources is also a trend from the sustainability perspective, as these inefficiencies can lead to increased environmental residuals, generated in this industry.

Dües et al. (2013) state that the LP implementation acts as a catalyst for the Green Manufacturing (GM) because it facilitates the process of transforming the industry in direction of a sustainable development.

Thus, green and lean practices can be defined in Green Manufacturing (GM) and Lean Production (LP) successively, as a set of techniques that will eliminate and/or reduce potential negative impacts of the production system on the organizational performance, decreasing, as a consequence, products and services consumption on that environment (Rao, 2005).

Nativi \& Lee (2012) point out that sustainability should be considered as the combination of environmental, economic and social factors, providing a comprehensive definition of the concept defined by John Elkington, as the Triple Bottom Line (TBL), which consists synthetically the economic prosperity, allied to the environmental quality, and the social justice.

Thus, the business operation must cause minimal environmental damage and be sustained based on the integration of social, economic and also environmental criteria. So, in relation to corporate performance against these pillars, industry needs financial returns and, at the same time, it must seek to maintain a balance between these three aspects so that the organization can be sustainable in the long term.

LP can be linked in some ways. It is a system that integrates from goods and services production at a minimum cost (Celis \& Sánchez García, 2012). For authors, it is also associated with: (i) waste disposal; (ii) inventory reduction; (iii) delivery time reduction; (iv) rework reduction; (v) financial savings; and (vi) of processes. In order to minimize the effects of variability in processing or demand time, in addition, LP considers that value is created by the industry, but must be defined by the customer perception.

Faced with this scenario for the search for greater productivity and because of the changes that occur in the market, organizations are required to adopt a new attitude towards their customers, competitors and suppliers, and their key business processes 
and the entire Supply Chain (CS). And through innovation and new strategic reorientation and production, in the sense of achieving corporate goals, the whole CS can become more competitive.

For this work accomplishment, a theoretical, exploratory, bibliographical and also descriptive review was carried out. The research conducted is of an applied nature, and methods of inductive and comparative approaches have been adopted. LP applicability concepts and tools were analyzed and, through a case study, the productive process of an industrial refrigeration furniture industry was investigated.

This paper is composed of the following sections: this first introductory part, the second for the theoretical framework, the third on methodological aspects, the fourth on case study and results analysis, and the last one dealing with final considerations.

\section{Industrial production systems}

The production systems, called "pushed systems", can be conceptualized as a production controlled by a planning center, which considers future demands forecasts (Gstettner \& Kuhn, 1996; Spearman et al., 1990). According to Huang et al. (1998), in a pushed system, a previous operation of the production process produces its part without waiting for the immediately subsequent operation request. According to Fernandes \& Godinho (2007), the system pushes production when the material flow has the same direction as the information flow.

On the other hand, production systems called "pulled systems" can be understood as a production program that authorizes the production of a given item according to the sales order made, or the task demanded by the subsequent station, rather than scheduling the production and the inventory (Spearman et al., 1990). Table 1 shows a comparation between the "pulled" and "pushed" production systems.

Table 1. Comparison between the systems of pulled production and pushed production.

\begin{tabular}{ccc}
\hline Productive System & Pushed & Pulled \\
\hline Production & Repetitive & Flexible \\
\hline System Improvements & Active & Passive \\
\hline Defects & Minimum & Medium/High \\
\hline Batch & Small & Medium/Big \\
\hline Control & Process & Product \\
\hline Work & Integrated & Tight \\
\hline Lay out & By Cells & By Sections \\
\hline Stocks & Low & High \\
\hline Demand Forecast & Small & Intense \\
\hline Operators & Multipurpose & Specialized \\
\hline
\end{tabular}

Source: Slack \& Lewis (2009).

These pull-production management systems seek to adjust output to demand for products, ie something will be produced, transported or purchased only at the exact moment it is needed and in the quantity that will be used, eliminating, for example, inter-process inventories. Figure 1 shows a simplified diagram with the main differences between the pushed system and the pulled system. 


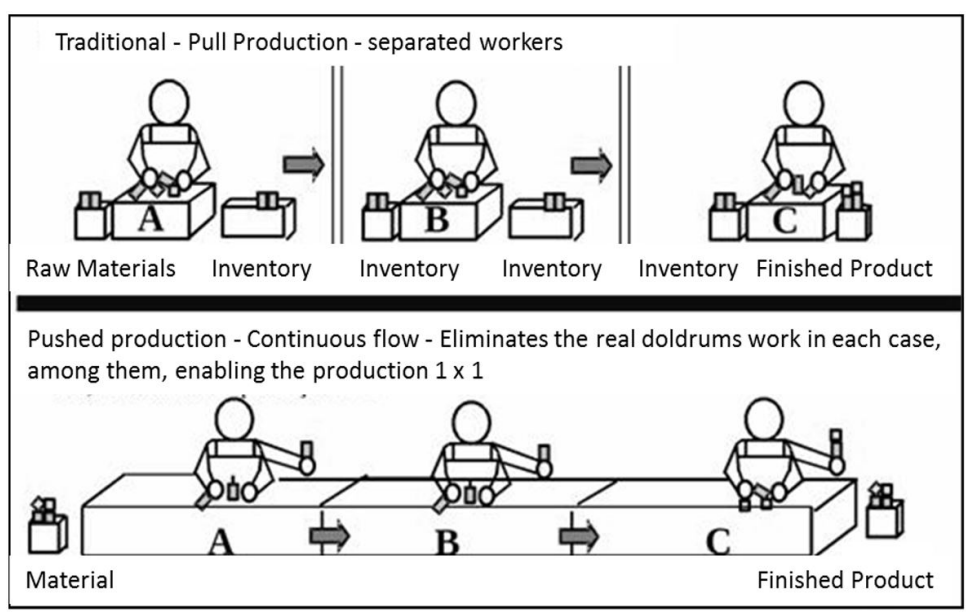

Figure 1. Differences between pushed and pulled production. Source: Lean Institute (2014).

\subsection{Production strategy}

The study of Baptista et al. (2013) found that the option for strategic change can be more successful if it is adopted by industries with a good financial performance because it requires continuous investments. Many changes are necessary to promote strategic changes in a productive system, which will present, currently and in the future, constant challenges to the organizational and behavioral procedures (Tavares \& Espanha, 2015). Menetti et al. (2015) corroborate with the understanding that the process result is mainly dependend of people behavior. Therefore, initially, it is fundamental that industries know and recognize the professionals who are part of their staff composition.

For Ohno (1997), what Japanese factories needed were to master the continuous flow and standardize manufacturing processes of a greater number of components through standardized labor, definition of production cells, modularization, and adaptable layouts.

According to Rother \& Shook (2003) to make improvements possible in the production process, in addition to standardization focus that provides higher productivity, it is necessary, initially, to know work procedures current and future states. Authors report that the application of some lean tools, such as Value Stream Mapping (VSM), can facilitate this visualization. There are two main steps in this context: (i) the current value stream (current state) is visualized and the flow layout is analyzed, verifying where there sources of waste, and; (ii) these identified wastes are reduced, and a new value stream map (future state) is added.

Under the LP context kanban is also considered, which consists of a technique that uses cards that works between consecutive workstations, being its main functions to regulate stock levels between them, in order to keep it as low as possible, and also to make the process pulled, without compromising production (Spearman et al., 1990). When the intermediate stock of the next workstation is reduced, the kanban allows production to start at the previous station (workcenter).

Another important element in LP is Kaizen, as Liker (2004) states, it is recognized through the administrative commitment of a company and permanent investment in personnel training, and in the promotion of a continuous improvement culture. According to Imai (1986) and Suárez-Barraza \& Miguel-Dávila (2011), it is a set of personal principles that transform people's "way of life," and guide people toward a 
search behavior for constant improvement. Authors complement, explaining that the word Kaizen is derived from two Japanese kanjis: KAI = change, and ZEN = for better.

Thus, Kaizen is the continuous improvement itself, as a logical, practical, objective and successful sequence of convergence. And by its application it can be measured quantitative and qualitative gains, and be recognized developed areas by its application.

The Just in Time (JIT) system seeks to reduce inventory, and incorporates aspects of materials management, continuous flow, quality management, physical arrangement, product design, work organization and human resources management to reduce inneficiencies (Correa \& Gianesi, 1993).

Cerra \& Bonadio (2000) report that there are many programs that can foster production improvements, among them JIT and Total Quality Management (TQM), which can jointly establish a Production Strategy that will contribute to the competitive priorities achievement.

Organizations need direction in order to take advantage of market opportunities. Theses opportunities can be generated through strategic production decisions. Slack \& Lewis (2009) highlight four perspectives regarding production strategies: (i) Top Down; (ii) Bottom Up; (iii) market requirements, and; (iv) exploitation of production resource capacities.

In order to verify which of these perspectives may be more feasible according to the organization status, it can be applied tools developed by Porter (1986) in his model of the five competitive forces (suppliers bargaining power, customers bargaining power, established competitors, new entrants, substitute products), which relates the organization to its environment, in order to understand the organization's situation and its positioning towards its competitors. Besides, how it can be obtained competitive advantage through actions that minimize these forces impact on the company. The author reports that the strategy is consolidated when competitors do not have and/or will delay to have the strategy put into action, and that advantage is obtained by synergic and different set of activities from competitors, or activities carried out in a different way, which comprise the generation and maintenance of distinctive competencies.

Bhasin (2012) corroborates, describing this strategy and competitive advantage feasible by costs reduction, eliminating waste and increasing responses to the threats and opportunities generated in this company environment, in the sense of business sustainability.

According to Hamel \& Prahalad (1995), industries should have strategic production and forecasting capabilities, and their managers should seek answers to questions involving their products and customers, identifying which benefits and capabilities are relevant to generate it. In addition, it is important to know the range of competition in which the industry is located, as well as what skills to develop, and with which strategies to compete.

According to Harrie (2011), the role of industry in the market must be clearly defined through the organization's strategic positioning, which depends on the interrelationship among mission, vision, values, goals, and the way in which this company will act in the market in search of competitive advantage.

Hitt et al. (2008) emphasize that for a company to achieve this positioning, it needs to create an infrastructure that includes activities necessary to support the entire Value Chain, activities that allow the identification of superior, equivalent or inferior capabilities to competitors. 
Slack \& Lewis (2009) argue that the industry must have competitive benefits, which will demonstrate differentials over competitors based on performance objectives such as quality, speed, reliability, flexibility and cost. Thus, the production strategy can be defined in several forms: in a radical, partial or incremental way, in addition to the production systems be pulled or pushed.

\subsection{Lean production}

According to Gonçales et al. (2016), Lean Production (LP) can be considered as a viable strategy, since a company is able to have short and long term planning. Authors have identified in the literature, through a systematic review, reports that LP practices in the search for improvement and development of production processes is not an easy task, and it can take long periods to reach maturity.

According to Womack \& Jones (2004) Lean Production (LP) or Lean Manufacturing $(\mathrm{LM})$ is considered a methodology that seeks to increase production using each time less resources, which means human effort, equipment use, time, movement and space; eliminating losses, and reducing the waste generation, increasing in this way industry benefits through activities that allow adding value to the final product. For the authors, there are seven types of LP losses: (i) superprocessing; (ii) overproduction; (iii) movements; (iv) waiting; (v) unnecessary stocks; (vi) defects, and; (vii) rework.

The LP model consists of the Toyota Production System (TPS), in which elements are assembled as a system, which makes it stand out as a whole and not in relation to its individual elements. Thus, this model success is related to the balance directed to people functions, and to the organizational culture, which seeks to value its continuous improvement, based on a technical system focused on high added value flow (Liker, 2004).

In this way, the key to TPS is not only in tools, techniques, Just in Time (JIT), Kanban, among others, but in the administrative commitment of an industry through a permanent investment in its personnel training, and the promotion of a culture of continuous improvement (Kaizen).

In this sense, LP can be defined as a strategy that depends on a set of practices aimed at minimizing defects, such as extra inventory, scrap, rework, waste identification and disposal at various stages of production processes, in order to improve the organizational performance (Nasab et al., 2012; Brunilde, 2013). In order to also achieve superior performance, world-class and continuous improvement (Gonçales et al., 2016).

On the other hand, in competitive world of organizations, the search for perfect products finds several strategies that aim to increase competitive advantage. Markets are increasingly more competitive, customer loyalty is increasingly disputed, and at the same time, organizations are constantly seeking mechanisms to achieve customer satisfaction. In this sense, concepts like Lean Six Sigma become important within the business context, for the results they provide.

According to Atmaca \& Girenes (2013), the Lean Six Sigma methodology is a combination of Lean Manufacturing or Lean Production, which began in the 1960s along with the Six Sigma methodology generated by Motorola in the 1980s. Both models provide operational support to add value to processes, quickly and efficiently.

The term Lean Management focuses on processess losses, with the objective of developing solutions using the least possible material, human or financial resources (Atmaca \& Girenes, 2013). According to authors, there are seven types of losses in the 
Lean system: (i) excess of production; (ii) defects; (iii) unnecessary inventory; (iv) inadequate treatment; (v) excessive transportation; vi) waiting time, and; (vii) unnecessary movements. Pyzdek \& Keller (2010) indicate that the Six Sigma implementation can contribute to these losses minimization / elimination. However, authors report that this implementation should follow five phases: define, measure, analyze, improve, control (DMAIC cycle).

According to Devane (2004), six sigma without lean approach results in the lack of three needed characteristics for the organization success: (i) direct focus on improving the process speed; (ii) direct attention to the amount investments in stocks; (iii) no short-term financial gains due to the time required to learn and apply methods and tools for data collection and analysis.

Therefore, Lean Six Sigma is a methodology that seeks continuous improvement to achieve customer satisfaction, cost, quality, and speed in the process. Lean Six Sigma starts with customers, and its purpose is well defined: eliminating waste, improving quality, and returning investments (Brook, 2010).

\section{Methodologic approach}

The present work, from its objectives point of view, is exploratory, bibliographical and also descriptive. The research conducted is of an applied nature, and the methods of inductive and comparative approach have been adopted (Gil, 2002; Lakatos \& Marconi, 2003; Prodanov \& Freitas, 2013).

To data collection, was used a specific technique, performed through interviews. It is also documentary. Gil (2008) emphasizes that documentary research is based on materials that have not yet received an analytical treatment, or that can be re-elaborated according to research objectives. At the time of questionnaire application, it was possible to access documents and information on the current financial results of the pushed system, and future after changing production system for pulled.

The technical procedure used was the single case study, which according to Miguel (2007), is composed of the following steps: STEP 1: Define a conceptual-theoretical framework. For this step a bibliographic review was carried out, via Journals Portal of the CAPES (Coordenação de Aperfeiçoamento de Pessoal de Nível Superior - Coordination of Improvement of Higher Level Personnel), and other sources. With focus on a research whose line was the analysis and the applicability of Lean Production (LP) concepts and tools, the productive process was investigated in a furniture company for industrial refrigeration sector. The theoretical conceptual framework was defined: (i) Lean Production, Pulled and Pushed Production Systems, Production Strategy, Kanban, Kaizen, Just in Time, DMAIC, and Lean Six Sigma. STEP 2: Case planning was carried out by a refrigeration furniture manufacturer located in the interior of São Paulo state, in the city of Jaú / SP. The surveyed company has an industrial complex with $5,000 \mathrm{~m}^{2}$ of construction and 70 employees. It owns an administrative structure and more than two decades of existence in the national market. The criterion of choice of the company was due to its technological initiatives, organizational innovation and interest in the development of its production processes. In this sense, the possibilities of the existence or the assimilation of Lean Production (LP) concepts are desirable, in order to serve an increasingly competitive market. There were three respondents: (i) Production Process Manager; (ii) Poductive Process Scheduler (PCP) and; (iii) Financial coordinator (controller). STEP 3: Data collection procedure occurs after the subject selection and research delimitation, bibliographic review and objectives definition. It were done two technical visits, and through 
the data collection instrument (interview) and with the presence of the researcher, respondents answered questions structured and oriented towards the proposed objective. Besides, information has been recorded. The interview was prepared, structured and performed following five criteria proposed by Cervo And Bervian (1996), being: (i) the interviewer should plan the interview, delineating carefully the objective to be achieved; (ii) choose interviewees according to the familiarity or authority with respect to the chosen subject; (iii) make a list of issues; (iv) ensure a minimum and sufficient number of respondentes; ( $v$ ) record the data during the interview, and complete their notes immediately after the interview ends. Therefore, the semi-structured interview with open questions was a quick response possibility, demanding on average 30 minutes per respondent. STEP 4: The data analysis procedure was based on the interviewed data collection, and initial results of the current and proposed production systems and the theoretical review of lean practices and tools were presented. Were used graphs, tables, figures and diagrams, according to the need of understanding and analyzing the problem situation. STEP 5: The final report was built with the theoretical implications from case study main results identification.

Thus, for this case study accomplishment, effects of the strategy change and the flexibility of the production of pushed to pull system were evaluated. In order to carry out the case study, a Six Sigma tool was used which, according to Pyzdek \& Keller (2010), is a rigorous, focused and highly efficient implementation of the quality techniques and principles. This tool called DMAIC stands for: defining, measuring, analyzing, improving and controlling improvements in the production system.

In detail, data were collected through the observation of productive departments, workers, material and information flows, inventory and activities of cutting, folding, assemblying, welding, and others to support production. Data were considered: time, displacement, productive hours, raw material, product, volume, fixed and variable costs, direct and indirect.

\section{Case study and results}

It was analyzed a case of flexibility due to the functional industrial production strategic system shift, from pushed to lean and pulled, considered in the design of departments and processes in the furniture company for industrial refrigeration sector. Three global factors were emphasized: volume, output, and time.

Stages of the shift were attended by the company main managers, interacting in the provision of general data to analyze changes possibilities in the production process, and the projection of possible results. The three respondents are processes managers closest to this research field: (i) Productive Process Manager; (ii) Prductive Process Scheduler (PCP) and; (iii) Financial Coordinator (controller). All have more than 3 experience years in the area.

The focus was, as recommended by the literature, on mastering the continuous flow and standardizing the manufacturing of as many components as possible, through standardized labor (standardized work in general), definition of production cells, modularization, and adaptive layouts.

The production process in this industrial segment is dependent on the physical spaces provided by the customers (available area of the property) and the measurements of the equipment of the various industrial manufacturers (ovens, stoves, plates, appliances, exhaustion devices, among others), and precisely due to this dependence, there is a great potential for gains from the applicability of LP concepts. 
As previously all the production was pushed, there were not standardization in excellence. All components and assemblies were produced based on technical specification and following make to order strategy, according to customers. This made the process slow and costly.

Initially, control of each stage of the production process inventory was done through Statistical Process Control (SPC), as well as measurements were taken and setups, processes cycles, and production lead times were analyzed.

Figure 2 shows the diagram of operations related to pulled production, as opposed to the current (pushed) system, in which the industry has historical results, worked in the last five years.

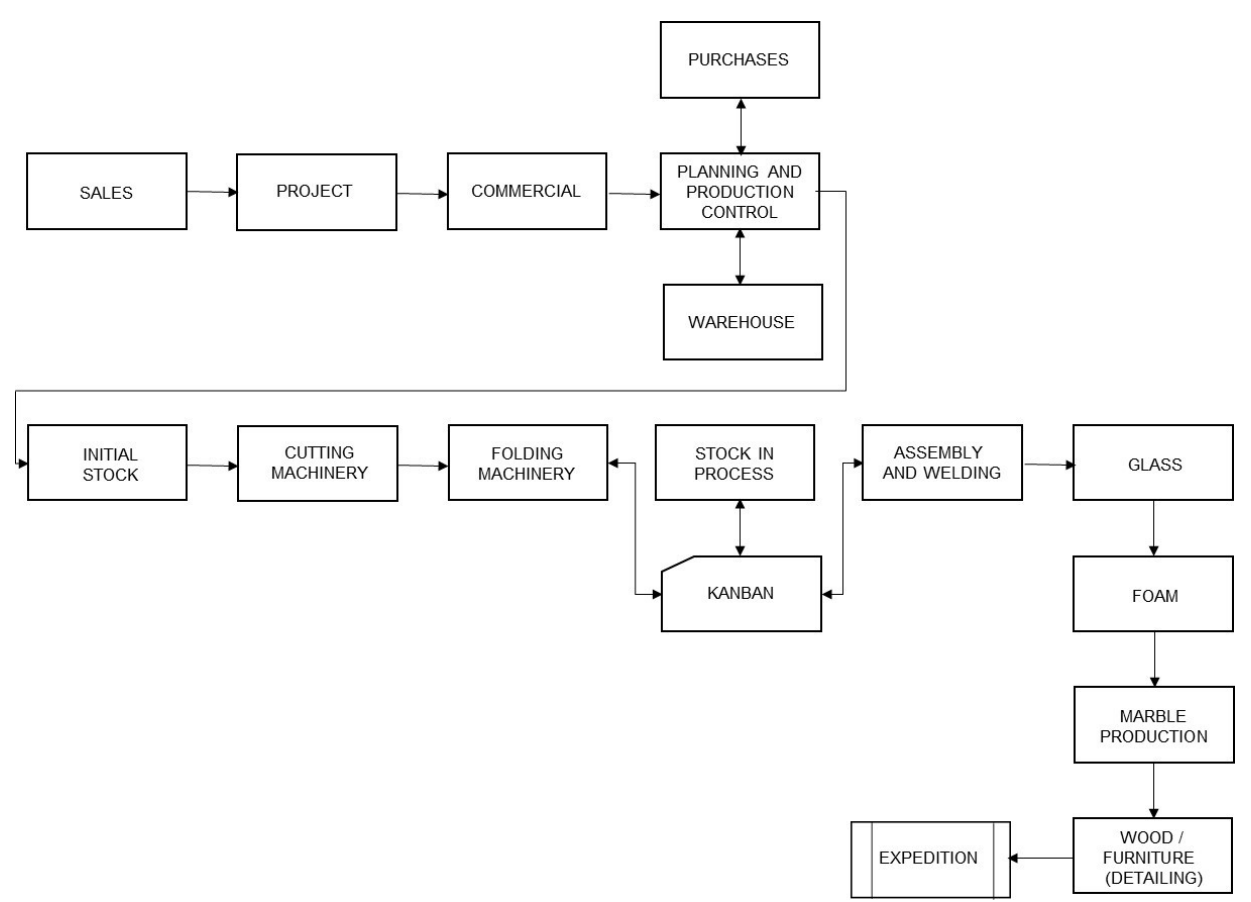

Figure 2. Simplified flowchart of the production system pulled layout, from the furniture factory for industrial refrigeration.

Afterwards, it was necessary to visualize the current value stream (current state) and perform the analysis of this layout flow, verifying where there waste sources, and then reducing these waste sources, creating a new value stream map (future state).

This application was carried out with the support of the DMAIC tool (define, measure, analyze, improve, control), on which actions are taken to change from the production system pushed to pulled. Thus, "D": Kaizen goals (improvements) were defined for the productive sectors; "M": The current situation was identified in the current value stream map (MFV) of the production lines was measured; "A": Projected MFG (future) and external demand, and between jobs were analyzed. Production lines were balanced and the workforce (DWF) required for the execution of all operations was defined. After execution and Improvement ("I"), the system was "C" Controlled and feedback with the correct and perceived deviations, as an uninterrupted cycle, fostering production processes continuous improvement. Thus, components and subassemblies that would be standardized and manufactured in series within an expected continuous flow were defined. 
Other components were also defined, those that are mounted on the ends of the furniture, and that would not be standardized and continue to be manufactured under special order and special measures. These components measurements mounted on the "ends" of the furniture would alternate to adjust and adapt to the physical spaces of the customers, and by different measures found in the equipment of several industrial manufacturers.

Therefore, it was possible to manufacture the possible components of continuous production, uninterrupted and according to the demand. Therefore, the production process has undergone the necessary changes and has adapted to LP concepts identified in the literature.

It was also possible to measure a production gain and turn them into financial results (in Reais - R\$), projected for the period of one year, as shown in Table 2.

Table 2. Vertical and horizontal analysis of the pushed and pulled systems.

\begin{tabular}{|c|c|c|c|}
\hline Results Elements & Pulled & Pushed & Variation \% \\
\hline Revenues & $18,614,315.06$ & $20,662,433.50$ & 9.91 \\
\hline Production (units) ${ }^{3}$ & 13,351 & 14,820 & 9.91 \\
\hline Labor (fixed costs) ${ }^{1}$ & $5,380,045.25$ & $5,020,045.25$ & -7.17 \\
\hline Other fixed costs ${ }^{1}$ & $1,025,330.46$ & $975,640.25$ & -5.09 \\
\hline Administrative salaries (fixed expenses) & $830,610.45$ & $830,610.45$ & 0.00 \\
\hline Total of fixed expenses & $7,235,986.16$ & $6,826,295.95$ & -6.00 \\
\hline Materials (variable costs) ${ }^{2}$ & $7,390,473.20$ & $7,390,473.20$ & 0.00 \\
\hline Other variables costs ${ }^{2}$ & $958,320.48$ & $958,320.48$ & 0.00 \\
\hline Total of variable expenses & $8,348,793.68$ & $8,348,793.68$ & 0.00 \\
\hline Total of expenses & $15,584,779.84$ & $15,175,089.63$ & -2.70 \\
\hline Operation Results & $3,029,535.22$ & $5,487,343.87$ & 44.79 \\
\hline
\end{tabular}

${ }^{1}$ Fixed expenses. ${ }^{2}$ Variable expenses. ${ }^{3}$ Total production in physical quantities.

These results were obtained in a projected amount, for a 12 months period, considering amounts for 2016 year, based on the accounting and financial information provided by the comppany.

The item "other fixed costs" involves mainly resources such as depreciation, electricity, planning / design and product development. It is observed that this item had a reduction of $5.09 \%$, in comparison with the production system pulled.

The overall and economic impact was positive and reflected in higher gross revenues, from $R \$ 18,614,315.06$ to $R \$ 20,662,433.50$, and Operating Income (RO) with a growth of $44.79 \%$.

Given that lean practices lead to the best use of existing resources, reducing production stops, machine setups, cycle time and hence lead time, so that these conditions contribute to maximize the economy and productivity.

Pulled output and the continuous flow in the production process also make the hours with supervision reduced. In this study, a gain of $7.17 \%$ was observed, and these hours can be better utilized in other processes, such as quality control, new product development, total productive maintenance (MPT), among others.

The quality continuous improvement was noticed by the lean behavior adopted and incorporated as a philosophy of life, by professionals. Gains went beyond minimizing the wastefulness, such as the use of excessive labor, unnecessary movement, 
inventory in process, and downtime. Were obtained continuity of the improvement achieved, that is, the new production system is maintained by the kaizen implemented.

It was also identified the increase of activities and processes that add value, registered as a positive result by the greater quantity of pieces produced in the same time, compared to what was produced in the pushed system. For example, 13,351 parts (total components) were produced in the pushed system, and 14,820 parts in the system pulled by means of kanban. The growth was $9.91 \%$.

The item related to the materials corresponds to the variable cost and has not been reduced as a function of the volume produced. This is due to the fact that in this system of pulled production there was no use of materials, compared to the pushed system.

\section{Final considerations}

With the adoption of Lean Production (LP) and lean thinking and behavior, and continuous flow, it was possible to reduce waste and promote improvements in the manufacturing process of the refrigeration furniture company.

It was adopted the kanban system, in the line supermarket, continuous flow and improvements were promoted. The production went from pushed to pulled according to demand and, through the balance of the line and reduction of raw materials stock in the productive sector, among the workstations, positive results were obtained.

The architecture associated with LP and its lean tools, evidenced especially by pulled production, kanban, continuous flow and kaizen, were responsible for the higher productivity indexes achieved.

Therefore, the change and flexibilization of the production system, transforming it from pushed to pulled by means of concepts and tools of the LP implementation, provided the development of the company productive processes. Benefits are evidenced by the waste elimination and higher productivity, market competitiveness and environmental benefits by reducion of electricity consumption, presented in the "other fixed costs" item. This is important, both economically and environmentally.

The constraints of the case study concern the adopted methodology, which restricts the results only for the industry researched. Nonetheless, it should be noted that results are benchmarks, and broaden the vision on how to promote an increase in competitive advantage through an operations strategy, called Lean Production (LP). Results are convergent with the literature, although it suggests other subjects that have not yet been sufficiently studied, and that require additional investigations.

Finally, indicated results permeated the method and were based on what was found in the available literature within CAPES Portal and other sources, and applied in a real case of the furniture industry for refrigeration, obtaining relevance, since there is a scientific gap in publications for the productive process of this sector. To date, no study of Production Engineering or Production Management interventions under the LP theme has been found in the presented way, with a focus on the proposal to flexibilization in the production process to reduce energy consumption and other expenditures, and to contribute for sustainability, economic and environmental. It is still relevant due the fact that production process in this industrial segment is dependent on physical spaces, made available by the customers and due to equipments sizes of several industrial manufacturers. Based on process type specificities, no previous research was done, and precisely due to this dependence, it was possible to present gains due to the applicability of the concepts of LP, such as: standardized work, 
definition of production cells, modularization, adaptive layouts, and adoption of the continuous flow.

Thus, this manuscript describes an original work with the potential to be cited by the stakeholders of the refrigeration furniture industry, students, and researchers in the area of Production Engineering and Production Management.

\section{References}

Associação Nacional de Fabricantes de Produtos Eletroeletrônicos - ELETROS. (2014). Retrieved in 2014, October 3, from http://www.eletros.org.br/

Atmaca, E., \& Girenes, S. (2013). Metodologia Lean Six Sigma e aplicação. Quality \& Quantity, 47, 2107-2127. http://dx.doi.org/10.1007/s11135-011-9645-4.

Baptista, C., Matias, F., \& Valle, P. (2013). Fatores moderadores da dependência do investimento relativamente à liquidez interna. Tourism \& Management Studies, 9(2), 71-77.

Bhasin, S. (2012). An appropriate change strategy for lean success. Management Decision, 50(3), 439-458. http://dx.doi.org/10.1108/00251741211216223.

Brook, R. H. (2010). The end of the quality improvement movement: long live improving value. Journal of the American Medical Association, 304(16), 1831-1832. http://dx.doi.org/10.1001/jama.2010.1555. PMid:20978261.

Brunilde, V. (2013). Combining organizational performance with sustainable development issues: the Lean and Green project-benchmarking repository. Journal of Cleaner Production. http://dx.doi.org/10.1016/j.jclepro.2013.12.023.

Caffyn, S. (1999). Development of a continuous improvement self-assessment tool. International Journal of Operations \& Production Management, 19(1), 1138-1153. http://dx.doi.org/10.1108/01443579910291050.

Celis, M. O., \& Sánchez García, J. M. (2012). Modelo tecnológico para el desarrollo de proyectos logísticos usando Lean Six Sigma. Estudios Gerenciales, 28(124), 23-43. http://dx.doi.org/10.1016/S0123-5923(12)70214-0.

Cerra, A. L., \& Bonadio, P. V. G. (2000). As relações entre estratégia de produção, TQM (Total Quality Management ou Gestão da Qualidade Total) e JIT (Just-In-Time): estudos de caso em uma empresa do setor automobilístico e em dois de seus fornecedores. Gestão \& Produção, 7(3), 305-319. http://dx.doi.org/10.1590/S0104-530X2000000300008.

Cervo, A. L., \& Bervian, P. A. (1996). Metodologia científica (4. ed.). São Paulo: Makron Books.

Correa, H. L., \& Gianesi, G. N. (1993). Just in Time, MRP II e OPT: um enfoque estratégico. São Paulo: Atlas.

Devane, T. (2004). Integrating lean six sigma and high-performance organizations: leading the charge toward dramatic, rapid and sustainable improvement. New York: Wiley.

Dües, C. M., Tan, K. H., \& Lim, M. (2013). Green as the new lean: how to use Lean practices as a catalyst to greening your supply chain. Journal of Cleaner Production, 40, 93-100. http://dx.doi.org/10.1016/j.jclepro.2011.12.023.

Fernandes, F. C. F., \& Godinho, M., Fo. (2007). Sistemas de coordenação de ordens: revisão, classificação, funcionamento e aplicabilidade. Gestão \& Produção, 2(2), 237-352. http://dx.doi.org/10.1590/S0104-530X2007000200011.

Gil, A. C. (2002). Como elaborar projetos de pesquisa (4. ed.). São Paulo: Atlas.

Gil, A. C. (2008). Métodos e Técnicas de Pesquisa Social (6. ed.). São Paulo: Atlas.

Gonçales, M., Fo., Campos, F. C., \& Assumpção, M. R. P. (2016). Revisão sistemática da literatura com análise bibliométrica sobre estratégia e Manufatura Enxuta em segmentos da indústria. Gestão \& Produção, 23(2), 408-418. http://dx.doi.org/10.1590/0104530×1683-14. 
Gstettner, S., \& Kuhn, H. (1996). Analysis of production control systems Kanban and CONWIP. International Journal of Production Research, 34(11), 3253-3273. http://dx.doi.org/10.1080/00207549608905087.

Hamel, G., \& Prahalad, C. K. (1995). Competindo pelo futuro: estratégias inovadoras para obter o controle do seu setor e criar os mercados de amanhã. São Paulo: Campus.

Harrie, W. M. (2011). A conceptual framework for analyzing sustainability strategies in industrial supply networks from an innovation perspective. Journal of Cleaner Production, 19(8), 895904. http://dx.doi.org/10.1016/j.jclepro.2010.12.015.

Hitt, M. A., Ireland, R. D., \& Hoskisson, R. E. (2008). Administração estratégica (7. ed.). São Paulo: Thomson.

Huang, N. E., Shen, Z., Long, S. R., Wu, M. C., Shih, H. H., Zheng, Q., Yen, N. C., Tung, C. C., \& Liu, H. H. (1998). The empirical mode decomposition and hilbert spectrum for nonlinear and nonstationary time series analysis. Proceedings of the Royal Society of London. Series A, 454(1971), 903-995. http://dx.doi.org/10.1098/rspa.1998.0193.

Imai, M. (1986). Kaizen: the key to Japan's competitive success. New York: Random House.

Kondo, Y., Hirai, K., Kawamoto, R., \& Obata, F. (2001). A discussion on the resource circulation strategy of the refrigerator. Resources, Conservation and Recycling, 33(3), 153-165. http://dx.doi.org/10.1016/S0921-3449(01)00081-7.

Lakatos, E. M., \& Marconi, M. A. (2003). Fundamentos de metodologia científica (5. ed.). São Paulo: Atlas.

Lean Institute. (2014). Retrieved in 2014, September 30, from http://www.lean.org.br

Liker, J. K. (2004). The Toyota way: 14 managements principles from the world's greatest manufacturer. New York: McGraw-Hill.

Menetti, S. A. P. P., Kubo, E. K. M., \& Oliva, E. C. (2015). A geração Y brasileira e o seu comportamento organizacional em empresas de conhecimento intensivo. Revista Portuguesa e Brasileira de Gestão, 14(2), 2-13.

Miguel, P. A. C. (2007). Estudo de caso na engenharia de produção: estruturação e recomendações para sua condução. Gestão \& Produção, 17(1), 216-229. http://dx.doi.org/10.1590/S0103-65132007000100015.

Nasab, H., Liheidari, B. T., \& Khademi, Z. H. (2012). Finding a probabilistic approach to analyze lean manufacturing Hosseini. Journal of Cleaner Production, 29-30, 73-81. http://dx.doi.org/10.1016/j.jclepro.2012.02.017.

Nativi, J. J., \& Lee, G. (2012). Impact of RFID information-sharing strategies on a decentralized supply chain with reverse logistics operations. International Journal of Production Economics, 136(2), 366-377. http://dx.doi.org/10.1016/j.jpe.2011.12.024.

Ohno, T. (1997). O sistema Toyota de produção: além da produção em larga escala. Porto Alegre: Bookman.

Porter, M. (1986). Estratégia competitiva: técnicas para análise de indústrias e da concorrência. Rio de Janeiro: Campus.

Porter, M., \& Linde, V. D. (1995). Green and competitive. Harvard Business Review, 73, 120134.

Prodanov, C. C., \& Freitas, E. C. (2013). Metodologia do trabalho científico [recurso eletrônico]: métodos e técnicas da pesquisa e do trabalho acadêmico (2. ed.). Novo Hamburgo: Feevale.

Pyzdek, T., \& Keller, P. (2010). The Six Sigma. New York: McGraw-Hill.

Rao, P. (2005). The greening of suppliers: in the South East Asian context. Journal of Cleaner Production, 13(9), 935-945. http://dx.doi.org/10.1016/j.jclepro.2004.04.010.

Rother, M., \& Shook, J. (2003). Aprendendo a enxergar: mapeando o fluxo de valor para agregar valor e eliminar o desperdício. São Paulo: Lean Institute Brasil. 
Ruan, J., \& Xu, Z. (2011). Environmental friendly automated line for recovering the cabinet of waste refrigerator. Waste Management, 31(11), 2319-2326.

http://dx.doi.org/10.1016/j.wasman.2011.06.004. PMid:21782408.

Slack, N., \& Lewis, M. (2009). Estratégia de operações. Porto Alegre: Bookman.

Spearman, M., Woodruff, D., \& Hopp, W. (1990). Conwip: a pull alternative to kanban. International Journal of Production Research, 28(5), 879-894. http://dx.doi.org/10.1080/00207549008942761.

Suárez-Barraza, M. F., \& Miguel-Dávila, J. A. (2011). Implementación del Kaizen en México: un estudio exploratorio de una aproximación gerencial japonesa en el contexto Latinoamericano, INNOVAR. Journal of Administrative and Social Sciences, 21(41), 19-37.

Tavares, A. T., \& Espanha, R. (2015). Marketing social: de curto passado a futuro promissor. Revista Portuguesa e Brasileira de Gestão , 14(3), 26-36.

Womack, J. P., \& Jones, D. T. (2004). Lean thinking: banish waste and create the wealth in your corporation. New York: Simon \& Schuster. 